\title{
PERSEPSI MAHASISWA STAKN KUPANG TENTANG PERBEDAAN ALIRAN GEREJA
}

\author{
Mieke Yen Manu \\ Sekolah Tinggi Agama Kristen Negeri Kupang \\ micmoc73545@gmail.com \\ Yanti Secilia Giri \\ Sekolah Tinggi Agama Kristen Negeri Kupang \\ yantigiri251@yahoo.com
}

\begin{abstract}
The issue of different church denominations has been one of the struggles faced by Christian churches for decades. This can be viewed as a form of wealth self-actualization of the church against the context of its existence, but on the other hand it can also be a source of schism in the unity of the body of Christ. The aim of this study was to determine the perceptions of STAKN's students about the differences in church denominations. The research method used is a quantitative approach through the study of descriptive statistics. Samples were taken by using probability sampling technique, namely a total of 105 respondents. The results of the research obtained the value of $t_{\text {count }}$ smaller than $t_{\text {table }}(-97,385<-1,983)$, so $\mathrm{H}_{0}$ is accepted and $\mathrm{H}_{1}$ is rejected. The conclusion is the perception of STAKN's students in Kupang concerning the differences in church denominations is in a quite positive category.
\end{abstract}

Keywords: church denominations, perception, the different

\begin{abstract}
Abstrak
Perbedaan aliran gereja merupakan salah satu pergumulan gereja yang rumit sejak dulu. Perbedaan aliran gereja dapat dipandang sebagai wujud kekayaan aktualisasi diri gereja terhadap konteks keberadaaan, namun di sisi lain dapat juga menjadi sumber perpecahan dalam kesatuan tubuh Kristus. Tujuan penelitian ini adalah untuk mengetahui persepsi mahasiswa Sekolah Tinggi Agama Kristen Negeri Kupang tentang perbedaan aliran gereja. Metode penelitian yang digunakan adalah pendekatan kuantitatif melalui studi deskriptif statistik. Sampel diambil dengan menggunakan teknik dari Probability Sampling yaitu sebanyak 105 responden. Instrumen yang digunakan dalam penelitian ini yaitu Angket. Hasil penelitian didapatkan nilai $t_{\text {hitung }}$ lebih kecil dari $t_{\text {tabel }}(-97,385<-1,983)$ sehingga $\mathrm{H}_{0}$ diterima dan $\mathrm{H}_{1}$ ditolak. Kesimpulan dari penelitian ini yaitu persepsi mahasiswa Sekolah Tinggi Agama Kristen Negeri Kupang tentang perbedaan aliran gereja berada pada kategori cukup positif.
\end{abstract}

Kata kunci: aliran gereja, perbedaan, persepsi, perbedaan 


\section{Pendahuluan}

Perbedaan aliran gereja adalah problematika gereja yang berpotensi menghadirkan konflik yang berkepanjangan. Secara sejarah, diketahui bahwa kekristenan terbagi menjadi dua kubu yang dikenal dengan sebutan Gereja Barat dan Gereja Timur, masing-masing dengan alirannya sendiri. Dalam penelitian ini, penulis akan lebih banyak berbicara pada sisi Gereja Barat, karena berbagai aliran gereja yang ada di Indonesia diimport dari Barat sebagai warisan dari kolonial. Gereja Barat sendiri terbagi dalam dua bagian besar yaitu Katolik Roma dan Protestan, dan dalam penelitian ini akan ditinjau dari sisi Protestan. Keberadaan setiap aliran gereja di Indonesia dipayungi oleh Dewan Gereja Indonesia (DGI) sehingga dapat diakui secara sah. Terlepas dari latar belakang pembentukkannya, DGI merupakan lembaga yang diharapkan dapat menjadi sarana pemersatu bagi keberagaman aliran gereja Protestan di Indonesia. Data dari tahun 1992 dinyatakan bahwa ada sekitar 700 organisasi Kristen Protestan yang ada di Indonesia dan sekalipun aliran yang dianutnya dapat terlihat dari nama organisainya, namun secara praktis banyak diantaranya menganut lebih dari satu aliran atau paham gerejawi. ${ }^{1}$

Sekolah Tinggi Agama Kristen Negeri (STAKN) Kupang merupakan lembaga perguruan tinggi yang menghasilkan para pengajar agama Kristen maupun para penyuluh agama Kristen dengan ruang lingkup kerja berkisar di sekolah maupun di gereja. Mahasiswa yang belajar di lembaga ini, paling tidak diharapkan memiliki pemikiran terbuka untuk menyingkapi berbagai perbedaan, termasuk perbedaan aliran gereja yang diwarisinya. Berdasarkan observasi yang dilakukan oleh penulis, diketahui bahwa mahasiswa STAKN Kupang terdiri dari berbagai golongan organisasi gereja, meskipun memang tidak ada data statistiknya. Hal yang menarik adalah penulis tidak menemukan indikasi konflik terkait perbedaan aliran gereja yang dianut masing-masing. Ketika ditelusuri lebih dalam mengenai hal ini, beberapa mahasiswa yang diajak berbincang menyatakan tidak mengetahui atau memahami perihal perbedaan aliran gereja. ${ }^{2}$ Beberapa lainnya yang menyadari perbedaan itu mengakui merasa tidak nyaman, namun memilih mengabaikan ketidaknyamanan tersebut dan terpaksa mengikuti kondisi yang ada saja. ${ }^{3}$ Dengan demikian, penelitian ini bertujuan untuk mengukur persepsi mahasiswa STAKN Kupang tentang perbedaan aliran gereja yang ada disekitarnya. Paling tidak hasil penelitian ini diharapkan dapat menjadi masukkan berharga bagi pengembangan pembelajaran agama Kristen yang aktual dan berbasis pada konteks.

\section{Perbedaan Aliran Gereja}

Menurut Kamus Besar Bahasa Indonesia, kata aliran memiliki beberapa arti, namun untuk konteks yang dimaksudpenulis, kata ini berarti haluan, pendapat, paham. ${ }^{4}$ Kata gereja berarti badan (organisasi) umat Kristen yang sama kepercayaan, ajaran, dan tata cara ibadahnya. ${ }^{5}$ Menurut Jan S. Aritonang, aliran gereja adalah keseluruhan ajaran dan pemahaman yang menjadi baku dalam kehidupan gereja. ${ }^{6}$ Maka penulis dapat menyatakan bahwa aliran gereja adalah paham yang dianut oleh badan atau organisasi umat Kristen (gereja), dalam hal ini gereja Protestan, yang merupakan hasil penghayatannya pada isi kitab suci (Alkitab) dan buah dari pergulatannya terhadap keberagaman latar belakang atau

2010).

${ }^{1}$ Jan S. Aritonang, Berbagai Aliran Di Dalam dan Di Sekitar Gereja (Jakarta: BPK Gunung Mulia,

${ }^{2}$ Mahasiswa jurusan PAK, wawancara dengan penulis, Februari 2018.

${ }^{3}$ Mahasiswa jurusan Pastoral Konseling, wawancara dengan penulis, Februari 2018.

4Ebta Setiawan, “Kamus Besar Bahasa Indonesia," KBBI Offline versi 1.1 (Freeware, 2010).

5Ibid.

${ }^{6}$ Aritonang, Berbagai Aliran Di Dalam Dan Di Sekitar Gereja. 
konteks keberadaannya dalam rangka melaksanakan amanat pelayanan di dunia. Bila menengok pada sejarah yang lebih awal, kekristenan berkembang menjadi tiga cabang utama yaitu Katolik, Protestan dan Ortodoks Timur. Namun yang menarik adalah hanya gereja Protestan yang terbagi dalam bermacam organisasi yang disebut denominasi, sedangkan gereja Katolik dan gereja Ortodoks Timur tidak menggunakan istilah denominasi. Tidak ada sumber yang menyebutkan secara pasti jumlah denominasi yang ada di kalangan Protestan, namun sejauh ini diperkirakan terdapat sekitar 33.000 denominasi Protestan. ${ }^{7}$ Dalam penelitian akan lebih banyak membahas tentang gereja Protestan dan beragam aliran maupun denominasinya.

Adapun keberagaman latar belakang, pergumulan dan konteks yang dihadapi gereja, kemudian melahirkan wujud atau sosok gereja yang terjelma dalam model denominasi yang beragam pula. Sekalipun demikian, selalu ada inti yang mengikat dan menyatukan keberagaman itu dalam nama gereja Protestan. Dengan kata lain, sekalipun setiap aliran gereja Protestan memiliki beberapa pemahaman dan penghayatan tertentu yang tidak seragam mengenai isi kitab suci tapi bagian yang paling mendasar akan selalu sama yaitu doktrin sola gratia, sola fide, dan sola scriptura, ${ }^{8}$ karena demikianlah nafas gerakan Reformasi Protestan. Berdasarkan buku Berbagai Aliran di Dalam dan di Sekitar Gereja yang ditulis oleh Jan S. Aritonang, terbahas 16 aliran gereja Protestan. Bila ditinjau dari runtut waktu kemunculan dapat dibedakan dalam 3 masa yaitu terhitung dari masa reformasi, masa revival, dan masa restorasi. Berikut ini daftar berbagai aliran gereja tersebut.

\section{Tabel 1. Asal Usul Aliran Gereja}

\begin{tabular}{|c|l|l|l|c|}
\hline No. & \multicolumn{1}{|c|}{ Aliran } & \multicolumn{1}{c|}{ Asal } & \multicolumn{1}{c|}{ Tokohpendiri } & Tahun \\
\hline 1 & Lutheran & $\begin{array}{l}\text { GKR (GerejaKatolik } \\
\text { Roma) }\end{array}$ & Marthin Luther & 1517 \\
\hline 2 & Calvinis & GKR & Johanes Calvin & 1534 \\
\hline 3 & Anglican & GKR & Raja Henri VIII & 1547 \\
\hline 4 & Mennonit & GKR dan Anabaptis & Menno Simons & 1537 \\
\hline 5 & Baptis & Mennonit & John Smyth & 1609 \\
\hline 6 & Methodist & Anglican & $\begin{array}{l}\text { John Wesley dan } \\
\text { Charles Wesley }\end{array}$ & 1787 \\
\hline 7 & Pentakosta & Methodist & Ch. F.Parham & 1900 \\
\hline 8 & Kharismatik & Episcopal & Dennis Bennett & 1960 \\
\hline 9 & Injili & Berbagaialiran & Billy Graham, dkk & 1930 \\
\hline 10 & Balakeselamatan & Methodist & William Both & 1878 \\
\hline 11 & Adventis & Methodist \&berbagaialiran & Ellen G.White & 1844 \\
\hline 12 & SaksiJehova & Presbyterian \&Adventis & Charles Taze Russel & 1879 \\
\hline 13 & Mormon & Presbyterian \& Methodist & Joseph Smith & 1830 \\
\hline 14 & Christian Science & Calvinis & Mary Morse Baker & 1879 \\
\hline 15 & Scientology & Christian Science & $\begin{array}{l}\text { Lafayette Ronald } \\
\text { Hubbard }\end{array}$ & 1954 \\
& & & Richard Albert & 1960 \\
\hline 16 & $\begin{array}{l}\text { New Age } \\
\text { Movement }\end{array}$ & Yahudi\& Scientology & & \\
\hline
\end{tabular}

${ }^{7}$ David B. Barrett, George Thomas Kurian, and Todd M. Johnson, eds., World Christian Encyclopedia: A Comparative Survey of Churches and Religions in the Modern World, 2nd ed. (Oxford $\square$; New York: Oxford University Press, 2001).

${ }^{8}$ Aritonang, Berbagai Aliran Di Dalam Dan Di Sekitar Gereja. 
Dari cabang besar gereja Protestan inilah berkembang ranting-ranting baru dengan coraknya masing-masing. Dengan kata lain, sekalipun terdapat perbedaan dalam hal-hal tertentu tapi tetap memiliki satu inti yang mengikat dan menyatukannya. Berdasarkan penyelidikan terhadap setiap aliran gereja, maka diketahui bahwa akar dari perbedaan adalah mengenai pemahaman dan penghayatan terhadap isi Alkitab ketika harus merefleksikannya dalam konteks keberadaannya di dunia. Setiap aliran memiliki sudut pandangnya sendiri dalam memahami isi Alkitab dan cara pengaktualisasian yang unik dalam kehidupan. Dengan kata lain, akar dari perbedaan itu terletak pada pokok pengajaran dan pola ritus yang nyata sehari-hari. Kedua aspek ini akan dibahas sebagai landasan untuk memahami secara menyeluruh perbedaan aliran dalam gereja Protestan.

a) Perbedaan pokok pengajaran

Dengan mempelajari sejarah maka nyata jelas bahwa setiap aliran gereja lahir dari latar belakang dan pergumulan yang berbeda-beda. Selalu ada oknum tertentu yang menjadi pelopor atau pendiri aliran tersebut. Dasar pemikiran tokoh tersebut dan pengumulannya dalam menghayati kebenaran Firman Tuhan menjadi warna yang khas dari aliran yang didirikannya.

Adapun pemikiran tokoh pendirinya selalu diklaim sebagai yang paling sesuai dengan kebenaran yang hakiki dari Firman Tuhan. Dan dalam perkembangannya menjadi pergerakan yang besar, pemikiran tersebut dibakukan menjadi pokok pengajaran yang diajarkan pada para pengikutnya. Namun yang disayangkan adalah klaim dari setiap aliran yang menyatakan diri paling benar dan menyalahkan ajaran aliran yang lain. Hal inilah yang sering kali menimbulkan pertentangan dan perpecahan yang lebih besar. Saling curiga dan prasangka buruk yang muncul semakin memperbesar jurang perpecahan dalam tubuh Kristus.

b) Perbedaan ritus harian

Tata cara peribadatan adalah salah satu bentuk yang paling nyata dan paling mudah dideteksi dari aliran-aliran yang berbeda. Untuk gereja yang berasal dari arus utama biasanya mempertahankan bentuk liturgi yang formal dan ibadah dilaksanakan dalam situasi yang sangat khidmat. Nyanyian dan musik Gregorian dari abad pertengahan masih digunakan dalam ibadah di gereja dan dipelihara sebagai warisan baik bahkan ditambah dengan lagu-lagu gubahan sejenis.

Sedangkan untuk aliran yang berasal dari semangat kebangunan rohani (Revival) menggunakan tata ibadah yang sederhana. Spontanitas dan tata ibadah yang lisan tanpa terikat liturgi tertulis memberi ruang bagi pengungkapan emosi yang dalam hingga kondisi ekstase. Nyanyian yang digunakan merupakan lagu-lagu baru dengan komposisi melodi yang sederhana, mudah dipelajari dan cepat populer. Dalam ibadah tidak hanya menggunakan organ atau piano tunggal tapi diiringi oleh band dan dipimpin oleh biduan tertentu.

Keadaan ini menimbulkan perbedaan pandangan yang cukup tajam dari setiap aliran yang saling berbeda tata ibadahnya. Aliran yang mempertahankan tata ibadah yang khidmat mengganggap aliran lain yang beribadah secara spontan sebagai bentuk kekacauan yang tidak menghormati kehadiran Allah dalam ibadah dan terkesan murahan. Demikian sebaliknya, aliran yang lebih spontan pun menuduh aliran yang tidak senada dengannya sebagai bentuk pengekangan terhadap pekerjaan Roh Kudus. Demikian anggapan dan prasangka yang semakin memperuncing perdebatan dan perpecahan tubuh Kristus.

\section{Persepsi}

Secara sederhana, persepsi merupakan proses penilaian seseorang terhadap segala sesuatu yang berada di sekitarnya. Menurut Walgito, persepsi merupakan hasil interpretasi 
dari proses stimulus yang diorganisasikan oleh sistem pengindraan sehingga diperoleh pengertian. ${ }^{9}$ Menurut Rakhmat, persepsi yang dihasilkan individu terbagi dalam dua bentuk yaitu persepsi positif (penerimaan atau dukungan terhadap objek) dan persepsi negatif (penolakan atau pertentangan terhadap objek). ${ }^{10}$ Dalam penelitian ini, digunakan teori komunikasi Stimulus-Organism-Responses (S-O-R) yang dikemukakan oleh Effendy. ${ }^{11}$ Dalam proses mengelolaan informasi (pesan/stimulus) oleh setiap individu akan berbeda satu dengan yang lainnya. Hal ini tergantung pada fungsi control diri dalam menanggapi stimulus, pengetahuan dan kemampuan berpikir, bahkan pengalaman. Dengan demikian, persepsi yang dihasilkan setiap indivudu pasti berbeda satu sama lainnya.

Berkaitan dengan penelitian ini, objek yang dipersepsikan adalah berbagai aliran gereja yang ada di lingkungan mahasiswa STAKN Kupang. Hal ini berarti mahasiswa akan melakukan persepsi terhadap objek non manusia yaitu:

a. Persepsi terhadap pokok ajaran yang berbeda untuk mengetahui apakah perbedaan tersebut dapat mengakibatkan penolakan yang menyebabkan perpecahan.

b. Persepsi terhadap tata ibadah atau liturgi yang beragam untuk mengetahui bentuk tata ibadah tersebut dapat menjadi bagian dari kekayaan kreatifitas gereja.

Adapun proses pembentukan persepsi mengikuti pola teori S-O-R, maka dapat dikemukakan sebagai berikut:

a. Stimulus adalah pengetahuan tentang perbedaan aliran gereja yang disampaikan melalui ruang-ruang kelas perkuliahan, karena salah satu kriteria yang ditetapkan bagi sampel penelitian adalah mahasiswa yang sudah mempelajari teologi dan pendidikan agama Kristen.

b. Organisme adalah mahasiswa tingkat III STAKN Kupang.

c. Respon adalah tanggapan atau persepsi dari mahasiwa setelah mengolah pesan yang diterima dan merupakan hasil yang dikejar dalam penelitian ini.

Dasarnya proses stimulus telah dilewati oleh responden penelitian karena dilakukan dalam masa perkuliahan. Informasi bisa saja diterima dengan jelas ataupun ditolak, dan tentu saja akan berpengaruh pada bagian selanjutnya yaitu mengelola informasi tersebut dalam pengertian. Maka penilaian akhir, entah positif ataupun negatif terhadap perbedaan aliran gereja, akan terlihat dari persepsi yang dihasilkan melalui penelitian ini. Adapun hipotesa yang diajukan dalam penelitian ini adalah persepsi mahasiswa tentang perbedaan aliran gereja sama dengan $70 \%$ dari yang diharapkan.

\section{Metode}

Penelitian ini menggunakan tipe penelitian survei, yaitu penelitian yang digunakan pada populasi besar maupun kecil, tetapi data yang dipelajari adalah data dari sampel yang diambil dari populasi tersebut, sehingga ditemukan kejadian-kejadian relatif, distribusi dan

${ }^{9}$ Harlina Nurtjahjanti, “Hubungan Antara Persepsi Terhadap Harga Dan Kualitas Produk Dengan Minat Membeli Produk Fashion Online shop di Facebook Pada Mahasiswa Politeknik X Semarang," Jurnal Psikologi Undip 11, no. 2 (n.d.): 8.

${ }^{10}$ Pebby Ayu Ramadhany, "Hubungan Antara Persepsi Remaja Terhadap Keberfungsian Keluarga Dengan Kematangan Emosi Pada Remaja Akhir," Jurnal Psikologi Perseptual 1, no. 1 (July 31, 2016): 10.

${ }^{11}$ Respon yang ditimbulkan adalah reaksi khusus terhadap stimulus khusus sehingga seseorang dapat mengharapkan dan memperkirakan kesesuaian antara pesan dari reaksi komunikan. Jadi unsur-unsur dalam model ini adalah pesan (Stimulus atau S), komunikan (Organism atau O) dan efek (Responses atau R). lih. Onong Uchjana Effendy (2003) dalam Dani Kurniawan, “Komunikasi Model Laswell dan Stimulus-Organism-Response Dalam Mewujudkan Pembelajaran Menyenangkan," Jurnal Komunikasi Pendidikan 2, no. 1 (January 31, 2018): 60. 
pengaruh dan hubungan-hubungan antarvariabel. ${ }^{12}$ Penelitian survey bertujuan mengumpulkan informasi tentang variabel dan bukan informasi tentang individu. ${ }^{13}$ Dalam arti bahwa informasi yang diperoleh bersifat data faktual yang akan dianalisis secara sistematis.

Penelitian ini dilaksanakan dari bulan Juni sampai bulan November 2018 yang berlokasi di STAKN Kupang. Adapun populasi yang ditentukan dalam penelitian ini adalah mahasiswa tingkat tiga STAKN Kupang, yang telah mempelajari ilmu teologi dan pendidikan agama Kristen. Populasi dimaksud terdiri dari tiga jurusan yaitu Pendidikan Agama Kristen (PAK) berjumlah 356 orang, Pastoral Konseling berjumlah 36 orang dan Musik Gerejawi berjumlah 28 orang. Jumlah total populasi adalah 420 orang.

Penulis tidak melakukan penelitian terhadap seluruh populasi, melainkan menggunakan teknik sampling. Adapun prosedur dalam pengambilan sampel penulis menggunakan salah satu teknik dari Probability Sampling yaitu dengan memberi peluang yang sama bagi setiap unsur (anggota populasi) untuk dipilih menjadi sampel. ${ }^{14}$ Dalam hal penentuan besaran sampel penelitian, penulis menggunakan teori yang dikemukakan oleh Arikunto yaitu apabila populasi berjumlah lebih dari 100 maka dapat diambil $25-30 \%$ dari jumlah tersebut. ${ }^{15}$ Berdasarkan jumlah populasi sebesar 420 orang, maka $25 \%$ sampel yang didapat adalah sebanyak 105 orang. Karena populasi terbagi dalam tiga jurusan yaitu PAK, Pastoral Konseling dan Musik Gereja, maka teknik sampling yang digunakan adalah Disproportionate Stratified Random Sampling dengan prosedur undian. Dengan demikian semua jurusan dapat terwakili dan proporsi yang sama. Maka jumlah sampel dari jurusan PAK sebesar 89 orang, jurusan Pastoral Konseling sebesar 9 orang, dan jurusan Musik Gerejawi sebesar 7 orang.

Pengumpulan data dalam penelitian ini dilakukan dengan menggunakan kuesioner (angket) yang disusun berdasarkan format skala Likert yang terdiri dari 4 pilihan jawaban dengan skor yang berbeda. Instrumen tersebut perlu memenuhi syarat-syarat tertentu agar data yang diperoleh dari pengukuran tersebut sahih (valid) dan terandalkan (reliable). ${ }^{16}$ Validitas ini menunjuk sejauh mana instrument tersebut mencerminkan isi yang dikehendaki. Selanjutnya jika hal itu terpenuhi, maka dimulai perhitungan indeks reliabilitasnya untuk melihat seberapa jauh tingkat keajengan instrument untuk mengukur variabel tersebut. ${ }^{17}$ Pengukuran validitas dalam penelitian ini mengunakan rumus korelasi Pearson Product Moment. Maka untuk jumlah responden uji coba 30 orang nilai r-tabel dengan taraf signifikansi 0,05 yaitu sebesar 0,361. Setelah dilakukan uji validitas, maka instru mendari item-item yang valid tersebut diuji reliabilitasnya. Hal ini dilakukan untuk melihat kehandalan dari instrument tersebut. Dalam arti apabila instrument tersebut digunakan untuk mengukur obyek yang sama akan menghasilkan data yang sama. Rumus yang digunakan adalah Alpha Cronbach, dengan batas minimal koefisiennya adalah 0,6. ${ }^{18}$

Penulis melakukan uji coba instrumen kepada 30 responden sebanyak dua kali dengan 12 butir item instrumen yang direncanakan. Hasil uji validitas ortogonal pertama diperoleh item valid sebanyak 7 item dan item drop sebanyak 5 item. Maka butir item yang

${ }^{12}$ Fred N. Kerlinger and Howard B Lee, Foundations of Behavioral Research (Forth Worth: Harcout College Publisher, 2000).

${ }^{13}$ Eliezer Sasmoko, Metode Penelitian, Pengukuran dan Analisis Data (Tangerang: Harvest Internasional Theological Seminary, 2005).

14Rully Indrawan and R. Poppy Yaniawati, Metodologi Penelitian (Bandung: PT Refika Aditama, 2014).

${ }^{15}$ Ibid.

16Sasmoko, Metode Penelitian, Pengukuran dan Analisis Data.

17Ibid.

18Sugiono, Metode Penelitian Kombinasi (Bandung: ALFABETA, 2015). 
drop dibuang dan diganti dengan pernyataan baru, lalu disebar kembali pada kelompok responden yang berbeda sebanyak 30 responden. Setelah hasil uji coba ortogonal kedua divalidasi diperoleh item valid sebanyak 12 item dan tidak terdapat item drop. Dengan demikian instrumen telah memenuhi kriteria kesahihan untuk dapat digunakan sebagai alat pengumpul data. Pengujian dilanjutkan dengan uji reliabilitas untuk memastikan konsistensi instrumen. Koefisien reliabilitas instrumen dianalisis dengan menggunakan rumus Alpha Cronbach dan diperoleh hasil sebesar 0,666 yang berarti berada pada kategori tinggi. Berdasarhan hasil pengujian validitas dan reliabilitas terbukti bahwa instrumen penelitian ini sahih dan andal, maka dapat digunakan untuk mengambil data penelitian.

Data penelitian yang terkumpul akan dianalisis dengan menggunakan analisa statistic-deskriptif. Analisa deskriptif setiap variabel dilakukan dengan pembuatan distribusi frekuensi variabel, histogram data kelompok, perhitungan mean, median, modus, standar deviasi, deskripsi setiap butir dan kecendrungan variabel. Hipotesa diuji dengan menggunakan rumus $t$-test satu sampel. Dalam analisis ini digunakan program computer yaitu Excel dan SPSS 20 for Windows.

\section{Hasil dan Pembahasan Hasil Penelitian}

Penelitian ini dilakukan untuk mengukur persepsi mahasiswa STAKN Kupang tentang perbedaan aliran gereja. Adapun hasil yang diperoleh adalah sampel sebesar 105 responden terdiri dari 19 responden yang berjenis kelamin laki-laki dan 86 responden berjenis kelamin perempuan. Kisaran umur responden adalah 19-33 tahun dengan sebaran terbesar adalah pada umur 22 tahun ( 25 responden) dan umur 23 tahun ( 24 responden). Aliran gereja yang paling banyak adalah Calvin, diurutan kedua adalah aliran Pentakosta, dan disusul secara berurut adalah aliran Kharismatik dan aliran Injili. Sebanyak 47,6\% responden tidak terlibat dalam pelayanan gereja, sedangkan sisanya yaitu 52,4\% responden terlibat aktif dalam pelayanan gereja. Jenis pelayanan gerejawi yang paling banyak melibatkan responden adalah Pelayanan Anak dan Remaja (PAR).

Data dalam penelitian ini dianalisa secara deskripsi kuantitatif dengan menggunakan pengukuran instrumen skala likert. Adapun instrumen terdiri dari 2 indikator yaitu perbedaan pokok ajaran dan perbedaan ritus harian setiap aliran gereja. Kedua indikator dimaksud tersaji dalam 12 item pernyataan dengan skor tertinggi adalah 4 dan skor terendah adalah 1 . Dengan demikian rentang minimum ideal dan maximum ideal adalah dari 12 sampai dengan 48. Maka kriteria penilaian objektif berpatokan pada tabel berikut.

Tabel 2. Kriteria interpretasi persepsi mahasiswa STAKN Kupang tentang perbedaan aliran gereja

\begin{tabular}{|c|c|}
\hline Kriteria skor penilaian & Interpretasi \\
\hline $39,10-48,00$ & Positif \\
\hline $30,10-39,00$ & Cukup positif \\
\hline $21,10-30,00$ & Kurang positif \\
\hline $12,00-21,00$ & Negatif \\
\hline
\end{tabular}

Berdasarkan hasil sebaran instrumen yang dibagikan terhadap 105 responden diperoleh nilai rata-rata (mean) adalah sebesar 36,19; simpangan baku (standar deviation) sebesar 3,557; varians (variance) sebesar 12,656; rentangan (range) sebesar17; skor terendah (minimum) sebesar28; skor tertinggi (maximum) sebesar 45. Gambaran lengkap data deskripsi statistik variable penelitian disajikan dalam tabel berikut ini. 
Tabel 3. Deskripsi statistik variabel persepsi mahasiswa STAKN Kupang tentang perbedaan aliran gereja

\begin{tabular}{|r|r|}
\hline Mean & 36,19 \\
\hline Std. Error of Mean &, 347 \\
\hline Median & 36,00 \\
\hline Mode & 37 \\
\hline Std. Deviation & 3,557 \\
\hline Variance & 12,656 \\
\hline Range & 17 \\
\hline Minimum & 28 \\
\hline Maximum & 45 \\
\hline Sum & 3800 \\
\hline
\end{tabular}

Adapun data distribusi frekuensi nilai variabel persepsi mahasiswa STAKN Kupang tentang perbedaan aliran gereja disajikan dalam tabel dan bar chart berikut.

Tabel 3. Distribusi frekuensi nilai variabel persepsi mahasiswa STAKN Kupang tentang perbedaan aliran gereja

\begin{tabular}{|r|r|c|r|r|}
\hline \multirow{2}{*}{ No. } & Rentang Skor & \multirow{2}{*}{ Kategori Skor } & \multicolumn{2}{|c|}{ Frekuensi } \\
\cline { 4 - 5 } & & & $\mathbf{N}$ & \multicolumn{1}{c|}{$\%$} \\
\hline 1 & $39,10-48,00$ & Positif & 19 & 18,1 \\
\hline 2 & $30,10-39,00$ & Cukup positif & 82 & 78,1 \\
\hline 3 & $21,10-30,00$ & Kurang positif & 4 & 3,8 \\
\hline 4 & $12,00-21,00$ & Negatif & 0 & 0,0 \\
\hline \multicolumn{2}{r}{} & Total & 105 & 100,0 \\
\hline
\end{tabular}

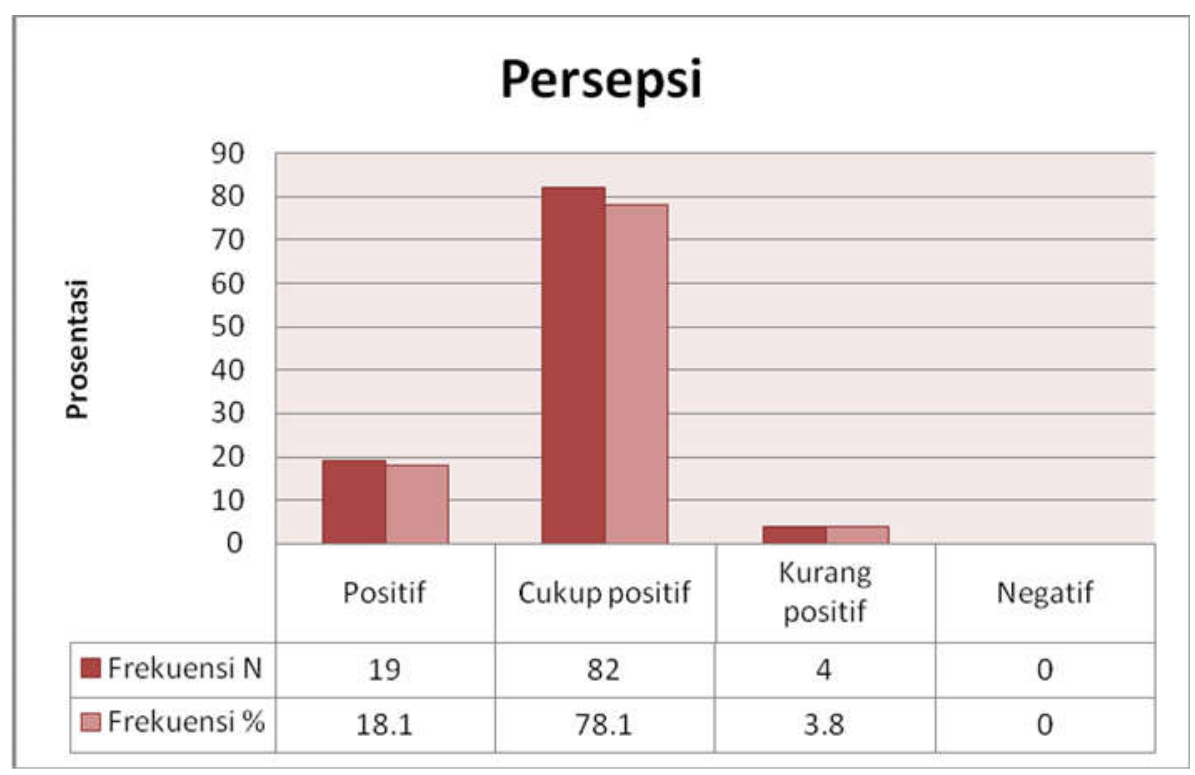

Gambar 1. Bar Chart distribusi frekuensi nilai variabel persepsi mahasiswa STAKN Kupang tentang perbedaan aliran gereja 
Dari tabel dan gambar tersebut dapat dijelaskan bahwa responden sebanyak 19 orang atau 18,1\% berada pada kategori positif. Sedangkan responden sebanyak 82 orang atau78,1\% berada pada kategori cukup positif. Responden penelitian yang berada pada kurang positif sebanyak 4 orang atau 3,8\% dan kategori negatif tidak ada. Dengan demikian dapat dikatakan persepsi mahasiswa STAKN Kupang tentang perbedaan aliran gereja berada pada kategori cukup positif ditandai dengan 101 jawaban responden atau 96,2\% berada pada skor rata-rata dan di atas rata-rata.

Sebelum melakukan analisis terhadap hipotesis, terlebih dahulu dilakukan uji persyaratan analisis yaitu uji normalitas. Uji normalitas dilakukan untuk mengetahui normal-tidaknya sebaran data yang akan dianalisis. Hasil penghitungan uji normalitas menyatakan bahwa data berdistribusi normal, selengkapnya dapat diperiksa pada tabel di bawah ini:

\begin{tabular}{|r|r|r|r|r|r|r|}
\hline \multicolumn{10}{|c|}{ Tabel 4. Tests of Normality } \\
\hline & \multicolumn{7}{|c|}{ Kolmogorov-Smirnova } & \multicolumn{4}{|c|}{ Shapiro-Wilk } \\
\cline { 2 - 7 } & Statistic & $\mathrm{df}$ & \multicolumn{1}{c|}{ Sig. } & Statistic & $\mathrm{df}$ & Sig. \\
\hline PERSEPSI &, 076 & 105 &, 161 &, 987 & 105 &, 409 \\
\hline \multicolumn{10}{|c|}{ a. Lilliefors Significance Correction }
\end{tabular}

Data di atas menunjukkan hasil perhitungan dalam rumus Kolmogorov-Smirnov (0,161 $>0,05)$ maupun Shapiro-Wilk $(0,409>0,05)$ yang sama-sama menyatakan bahwa sebaran data berdistribusi normal. Oleh karena itu, analisa dapat dilanjutkan pada uji hipotesis penelitian yaitu dengan menggunakan rumus uji $t$ one sample. Adapun Hasil uji $t$ dan nilai signifikansinya dapat dilihat dalam tabel di berikut ini.

\begin{tabular}{|r|r|r|r|r|}
\hline \multicolumn{5}{|c|}{ Tabel 5. Uji tOne-Sample Statistics } \\
\hline & $\mathrm{N}$ & Mean & $\begin{array}{c}\text { Std. } \\
\text { Deviation }\end{array}$ & $\begin{array}{c}\text { Std. Error } \\
\text { Mean }\end{array}$ \\
\hline PERSEPSI & 105 & 36,19 & 3,557 &, 347 \\
\hline
\end{tabular}

\begin{tabular}{|c|c|c|c|c|c|c|}
\hline \multicolumn{7}{|c|}{ One-Sample Test } \\
\hline & \multicolumn{6}{|c|}{ Test Value $=70$} \\
\hline & \multirow[t]{2}{*}{$\mathrm{t}$} & \multirow{2}{*}{ df } & \multirow{2}{*}{$\begin{array}{l}\text { Sig. (2- } \\
\text { tailed) }\end{array}$} & \multirow{2}{*}{$\begin{array}{c}\text { Mean } \\
\text { Differenc } \\
\mathrm{e}\end{array}$} & \multicolumn{2}{|c|}{$\begin{array}{l}\text { 95\% Confidence } \\
\text { Interval of the } \\
\text { Difference }\end{array}$} \\
\hline & & & & & $\begin{array}{c}\text { Lowe } \\
\mathrm{r}\end{array}$ & Upper \\
\hline $\begin{array}{l}\text { PERSEPS } \\
\text { I }\end{array}$ & $\begin{array}{r}- \\
97,38 \\
5\end{array}$ & $\begin{array}{r}10 \\
4\end{array}$ & , 000 & $-33,810$ & $-34,50$ & $-33,12$ \\
\hline
\end{tabular}

Dari tabel di atas dapat dianalisis bahwa nilai uji t sebesar $-97,385$ dengan nilai signifikansinya adalah 0,000 . Selanjutnya nilai $t_{\text {hitung }}$ diperbandingkan dengan nilai $t_{\text {tabel }}$ $(1,983)$; karena nilai $t_{\text {hitung }}$ lebih kecil dari nilai $t_{\text {tabel }}(-97,385<-1,983)$ maka dapat dinyatakan 
bahwa $\mathrm{H}_{0}$ diterima dan $\mathrm{H}_{1}$ ditolak. Jadi, hipotesa yang berbunyi persepsi mahasiswa STAKN Kupang tentang perbedaan aliran gereja sama dengan $70 \%$ dari yang diharapkan dapat diterima.

\section{Pembahasan}

Teori persepsi yang digunakan dalam penelitian ini adalah teori komunikasi SOR (Stimulus-Organism-Respon). Penulis menggunakan teori ini untuk menganalisa hasil temuan penelitian. Proses stimulus terjadi melalui proses pembelajaran di kelas dan juga tidak menutup kemungkinan bagi stimulus dari lingkungan keseharian responden. Organism adalah mahasiswa tingkat III yang sudah mempelajari mengenai sejarah Gereja di dunia maupun di Indonesia. Responden (organism) mengorganisir setiap informasi yang diperoleh hingga membentuk persepsi (respon). Dalam latar belakang diketahui bahwa di kalangan mahasiswa (responden) hamper tidak ditemukan konflik berkaitan dengan perbedaan aliran gereja. Penyebabnya adalah kurangnya pemahaman responden mengenai topic perbedaan aliran gereja dan beberapa responden lain memilih beradaptasi dengan kondisi yang ada sekalipun secara terpaksa. Hasil penelitian menunjukkan bahwa tidak ada responden yang memiliki persepsi negatif (respon) mengenai perbedaan aliran gereja, hampir seluruhnya sudah berada pada kategori cukup positif hingga kategori positif $(96,2 \%)$.

Berkaitan dengan temuan ini, penulis dapat menyimpulkan bahwa sekalipun dalam penyelidikan awal terdapat responden (organism) yang mengaku tidak memahami topik perbedaan aliran gereja, namun karena telah melalui proses stimulus sejak tingkat I hingga tingkat III, maka sebenarnya persepsi (respon) telah terbentuk. Demikian pula dengan responden (organism) yang beradaptasi secara terpaksa, juga mengalami proses stimulus yang sama sehingga persepsinya (respon) telah terbentuk menjadi toleran terhadap perbedaan aliran gereja. Proses stimulus yang diperoleh melalui pembelajaran di kelas diorganisir oleh setiap responden sehingga membentuk respon yang positif sejalan dengan kematangan intelektualnya.

Namun demikian, hasil penelitian juga menunjukkan bahwa masih ada sekitar 3,8\% responden yang berada pada kategori kurang positif. Dalam penelitian yang dilakukan oleh Kurniawan, teori SOR mengandung tiga komponen utama yang menentukan keberhasilannya yaitu stimulus harus mengandung perhatian, pengertian dan penerimaan. ${ }^{19}$ Sejalan dengan itu, penelitian yang dilakukan oleh Amalia menunjukkan bahwa penyampaian stimulus (informasi) yang tidak didukung oleh metode dan media yang memadai dan dapat dimengerti oleh organism maka respon yang dihasilkanakan negative. ${ }^{20}$ Dengan demikian, kondisi ini menjadi pekerjaan rumah bagi para pengajar, khususnya pengajar di STAKN Kupang untuk berusaha menyajikan materi perkuliahan (stimulus) yang berimbang tanpa memihak pada salah satu aliran tertentu sehingga meminimalis sikap diskriminasi terhadap aliran gereja yang berbeda.

\section{Kesimpulan}

Berdasarkan hasil analisa data penelitian, maka penulis dapat memberikan kesimpulan bahwa persepsi mahasiswa STAKN Kupang tentang perbedaan aliran gereja berada pada kategori cukup positif dengan hasil perhitungan mean sebesar 36,19. Pengujian hipotesa diperoleh hasil perhitungan $t_{\text {hitung }}$ lebih kecil dari nilai $t_{\text {tabel }}[-97,385<-1,983]$ yang berarti $\mathrm{H}_{0}$ diterima dan $\mathrm{H}_{1}$ ditolak. Dengan nilai signifikansi 0,000 $<0,05$ maka hasil

\footnotetext{
${ }^{19}$ Kurniawan, “Komunikasi Model Laswell Dan Stimulus-Organism-Response Dalam Mewujudkan Pembelajaran Menyenangkan."

${ }^{20}$ Gianita Rezki Amalia, “Opini Wanita Usia Subur Terhadap Kegiatan Penyuluhan Jaminan Persalinan Di Surabaya," journal.unair.ac.id (2019).
} 
penelitian ini dapat digeneralisasikan kepada populasi karena hasil perhitungan jatuh pada wilayah penerimaan $\mathrm{H}_{0}$. Dengan demikian asumsi awal dalam kerangka berpikir telah terjawab.

\section{Implikasi dan Rekomendasi}

Sehubungan dengan hasilpenelitian, maka saran yang dapat diberikan antara lain, pertama bagi mahasiswa, bahwa proses perkuliahan merupakan salah satu faktor penting pembentuk paradigma berpikir yang dapat mempengaruhi persepsinya terhadap lingkungan kehidupannya. Oleh karena itu, mahasiswa harus dapat menyeleksi informasi yang diterima, khususnya mengenai perbedaan aliran gereja agar dapat bertindak sesuai kapasitasnya sebagai makluk intelektual yang selalu menjunjung tinggi kemurnian akhlak serta menghindari perpecahan. Kedua bagi pengajar, agar dapat menjadi sumber informasi yang menyediakan bahan pembelajaran dapat mengubah paradigma lama yang apatis dan negatif, khususnya mengenai perbedaan aliran gereja. Para pengajar dapat mengarahkan mahasiswa untuk bertindak secara bijaksana dan tidak menimbulkan perpecahan karena pola pikir yang dangkal. Dan ketiga bagi lembaga, dalam hal ini STAKN Kupang agar dapat bertindak sebagai fasilitator bagi terlaksananya proses pendewasaan paradigma berpikir mahasiswa, khususnya mengenai perbedaan aliran gereja. STAKN Kupang diharapkan dapat terbuka dan merangkul setiap latar belakang aliran gereja yang berbeda dari seluruh civitasnya, sehingga dapat menjadi pioner bagi kesatuan gereja Tuhan di kota Kupang.

\section{Rujukan}

Amalia, Gianita Rezki. “Opini Wanita Usia Subur Terhadap Kegiatan Penyuluhan Jaminan Persalinan Di Surabaya." journal.unair.ac.id (2019).

Aritonang, Jan S. Berbagai Aliran Di Dalam Dan Di Sekitar Gereja. Jakarta: BPK Gunung Mulia, 2010.

Barrett, David B., George Thomas Kurian, and Todd M. Johnson, eds. World Christian Encyclopedia: A Comparative Survey of Churches and Religions in the Modern World. 2nd ed. Oxford $\square$; New York: Oxford University Press, 2001.

Indrawan, Rully, and R. Poppy Yaniawati. Metodologi Penelitian. Bandung: PT Refika Aditama, 2014.

Kerlinger, Fred N, and Howard B Lee. Foundations of Behavioral Research. Forth Worth: Harcout College Publisher, 2000.

Kurniawan, Dani. "Komunikasi Model Laswell Dan Stimulus-Organism-Response Dalam Mewujudkan Pembelajaran Menyenangkan." Jurnal Komunikasi Pendidikan 2, no. 1 (January 31, 2018): 60.

Nurtjahjanti, Harlina. "Hubungan Antara Persepsi Terhadap Harga Dan Kualitas Produk Dengan Minat Membeli Produk Fashion Onlineshop Di Facebook Pada Mahasiswa Politeknik X Semarang." Jurnal Psikologi Undip 11, no. 2 (n.d.): 8.

Ramadhany, Pebby Ayu. "Hubungan Antara Persepsi Remaja Terhadap Keberfungsian Keluarga Dengan Kematangan Emosi Pada Remaja Akhir." Jurnal Psikologi Perseptual 1, no. 1 (July 31, 2016): 10.

Sasmoko, Eliezer. Metode Penelitian, Pengukuran Dan Analisis Data. Tangerang: Harvest Internasional Theological Seminary, 2005.

Setiawan, Ebta. “Kamus Besar Bahasa Indonesia." KBBI Offline versi 1.1. Freeware, 2010.

Sugiono. Metode Penelitian Kombinasi. Bandung: ALFABETA, 2015. 